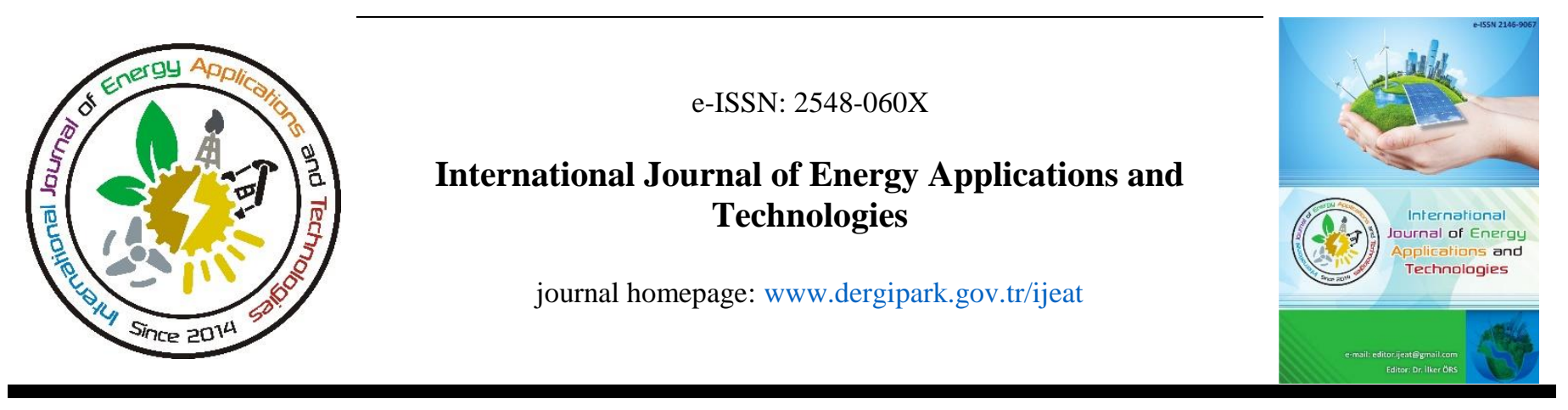

Original Research Article

\title{
Comparative study on wind energy potential for Artvin
}

\author{
Enes Halit Aydın ${ }^{1}$ Mehmet Çunkaş²* \\ ${ }^{1}$ Artvin Vocational School, Artvin Çoruh University, Artvin, Turkey \\ ${ }^{2}$ Department of Electrical and Electronics Engineering, Faculty of Technology, Konya, Turkey
}

\author{
ARTICLE INFO \\ * Corresponding author \\ mcunkas@selcuk.edu.tr \\ Received March 13, 2019 \\ Accepted September 11, 2019 \\ Published by Editorial Board \\ Members of IJEAT \\ C This article is distributed by \\ Turk Journal Park System under \\ the CC 4.0 terms and conditions.

\begin{abstract}
This paper presents a comparative study on wind energy potential for Artvin, which has a very rugged terrain and is in the east of Turkey and the Black Sea. Wind energy potential is computed with Numerical methods such as Weibull, Rayleigh, Gamma, and Lognormal distributions by using hourly wind speed data. Monthly wind energy density is determined between June 2017 and September 2018. The current map data of the General Directorate of Renewable Energy and the solar radiation amounts, and wind speed potentials obtained from Artvin Meteorology Directorate of the province are used. As a result of the calculations, the wind power obtained from the Weibull, Rayleigh, Gamma and Lognormal distributions is compared. It is shown that the weibull distribution produces more stable results.
\end{abstract}

Keywords: Wind energy potential; Statistical methods; Renewable energy; Artvin

\section{Introduction}

When considering the energy potential of Turkey in the past years, the increase in renewable energy sources is seen as moving rapidly toward the desired level. Turkey's aim in 2023 is to be among the world's 10 largest economies, to increase the share of renewable energy in the total energy supply to $30 \%$, and to invest in nuclear technology. Turkey is a country rich in terms of solar and wind energy potential. The efficient use of these energies will significantly reduce the dependence on imported energy and reduce the current deficit. As of July 2018, 26.2\% of the installed capacity of 87.138.7 MW is natural gas, $23.3 \%$ is hydroelectric power plant, $21.9 \%$ is fossil fuels, $7.6 \%$ is wind and the rest is other energy resources. The unlicensed wind, solar, thermal and hydroelectric power plants in production is $5.7 \%$. The share of unlicensed wind solar thermal and hydroelectric power plants in production is $3.4 \%$ [1]. In addition, it is seen that the electricity installed capacity increased by $1.9 \%$ compared to the previous year and the contribution of renewable resources to production increased by $2.3 \%$ compared to the previous year. According to TEIAS's August 2018 data, the production of electricity from domestic sources raised to $48.97 \%$. Considering that the electricity consumption has increased every year, it is necessary to raise the domestic rate in production as soon as possible. There are some studies in the literature on the potential of wind energy using statistical methods. Cho et. (2004) investigated the spatial characteristics of the nonzero rain rates with a probability density function (PDF) using the rain data from the tropical rainfall survey center. Gamma and lognormal distributions were used for this study and they observed that Gamma for wet areas and Lognormal distribution for dry areas had better performance [2]. Kurban et. (2007) aimed to determine wind and solar energy potentials by means of measurement stations and set up a hybrid power plant in Anadolu University's Campus and used the statistical distribution 
functions of Weibull and Rayleigh for analysis of wind energy potential. They found that the Weibull distribution has less error analysis. [3]. Çunkaş and Demirkol(2014) performed calculations based on the Weibull and Rayleigh distributions using hourly wind data for Afyonkarahisar, Sultandağ 1 and Dinar regions, and they concluded that Rayleigh distribution is more suitable for modelling the studied region [4]. Köse et. (2015) carried out the modeling of wind speed data of Eskipazar district of Karabük province with Weibull, Rayleigh and Lognormal distributions, and compared the power density data obtained from these data with actual data. The mean error squares sum (RMSE) and the coefficient of determination $\left(\mathrm{R}^{2}\right)$ were used for the performance analysis. As a result of their evaluation, it is shown that the Weibull function produces better results [5]. Balpetek and Akpinar(2017) conducted a statistical analysis of the wind speed parameters in Elazig province by using the wind speed data measured hourly. Weibull and Rayleigh distributions were used for modeling and they evaluated the performance of this modeling according to $\mathrm{R}^{2}$ and RMSE. Accordingly, the authors showed that the Weibull distribution was better than the Rayleigh distribution in the analysis of wind data of the province of Elazig. [6]. Usta and Kantar (2016) evaluated the performance of Weibull, Rayleigh, Log-normal, Gamma, Generalized Gamma, and Nakagami distributions by various criteria. Nakagami distribution has not been used in the energy field. The authors studied the performance of the mentioned methods using data from Turkey's wind speed measured in different regions. As a result of the analyzes, they concluded that the performance of the Nakagami distribution was as good as the other distributions and that it could be used as an alternative solution in the calculation of the power density of wind energy [7]. Emeksiz et al. (2016) carried out the analyses of wind potential by using the daily average wind velocity data of the years 2000-2010 obtained from Tokat Meteorology Station Directorate. They used Weibull, Rayleigh, Lognormal and Gamma distribution functions and discussed the Least Squares Method, which has a smaller standard deviation value in determining the parameters of the distributions. Root mean square error (RMSE) and mean square error (MSE) criteria were used for performance comparison. As a result, it is seen that the average wind speed values in February and March were high in November and December. Considering the MSE and RMSE values, they found that the Weibull distribution was more reliable than other methods [8]. Sohoni et al. (2016) used five probability distribution functions to fit wind velocity data from four different geographical regions of the world. The three functions called Weibull, Rayleigh and Gamma, which gave a better result, were chosen as priority. Evaluation of the parameters was done by RMSE and $\mathrm{R}^{2}$ criteria [9].
In this study, the wind energy potential of Artvin province was evaluated by using four numerical methods such as Weibull, Rayleigh, Gamma and Lognormal distributions. The data used in the study were taken from the General Directorate of Meteorology. The measurement of the data was carried out by using a wind measurement pole having a height of 10 meters through the measuring station at a height of 680 meters. The wind speed data for the period between June 2017 and September 2018 were obtained on an hourly basis. Monthly wind energy density for this station was estimated using Weibull, Rayleigh, Gamma and Lognormal distributions. The performance of these numerical methods was also analyzed and shown graphically. In addition, a brief review is conducted for the solar energy potential of the region. This study is an extended version of the previous study [10]. In the previous study, Weibull and Rayleigh distributions are used for determining wind power potential. In this study, in addition to Gamma and Lognormal distributions are utilized and also four methods are compared with each other.

\section{Renewable Potential in Artvin}

\subsection{Solar energy}

The Sun, which is the life source of the world, is also the source of the energy that human beings need to sustain their lives. The sun is located approximately 150 million $\mathrm{km}$ from the earth and the fusion process in its core generates energy. Solar energy is preferred because of its advantages such as being environmentally friendly and maintenance-free. In addition, the global solar energy potential of the part of the sunrays reaching the earth is 160 times the number of fossil fuel reserves that have been determined in the world. In other words, fossil, nuclear and hydroelectric plants on Earth are 15000 times more than they will produce in a year $[11,12]$. The process of formation of petroleum, coal and natural gas, which we call fossil fuels, has also been the result of the sun. Today renewable energy sources have gained importance as an alternative to fossil fuel based energy sources that are facing extinction. In addition to PV (photovoltaic) power plants that generate electricity from direct sunlight, indirect solar energy sources such as hydropower, wind and biomass are renewable energy sources. According to the data of the Ministry of Energy and Natural Resources, investments in solar energy in the world increased by $25 \%$ in the previous years and exceeded $\$ 150$ billion. The total solar energy of the world is 1.5 quadrillion MW / h per year. This amount of energy is equivalent to 28.000 times the energy consumed by people in the world in one year. If only $0.1 \%$ of this energy reaching the Earth's surface can be converted to electrical energy with a efficiency of $10 \%$, it can generate 4 times of the global electrical energy capacity of 3,000 GW. [13, 14]. 
Turkey is extremely rich in terms of solar energy potential. It is known to have an annual 380 billion $\mathrm{kWh}$ energy potential. Turkey's average annual solar radiation is $1,527 \mathrm{kWh} / \mathrm{m}^{2}$ year, while the average annual sunshine duration is 2,741 hours. These values correspond to a daily average of 4.18 $\mathrm{kWh} / \mathrm{m}^{2}$ of global radiation value and a daily average of 7.5 hours of sunshine. As of the end of June 2018, the total installed capacity of the PV solar power plant is 4,726 MW. In Turkey, electricity installed capacity (all power plants) was $78 \mathrm{GW}$ in 2016, while it reached $82 \mathrm{GW}$ as of October 31,2017 . In 2018 agenda focuses on domestic energy moves in Turkey. $[15,16]$. Turkey is one of the countries with the highest solar potential in Europe. According to the 2017 Renewable Energy Statistics Report of the International Renewable Energy Agency (IRENA), in terms of installed capacity of photovoltaics, 2016 was ranked 25th among the world countries with $844 \mathrm{MW}$. At the end of 2017, it reached the 13th place with a capacity of $3.422 \mathrm{MW}$. In the ranking of European countries, it ranked 15th in 2016 and climbed to 7 th in 2017. In recent years, Turkey is also the country with the most growth in terms of installed solar power [17].

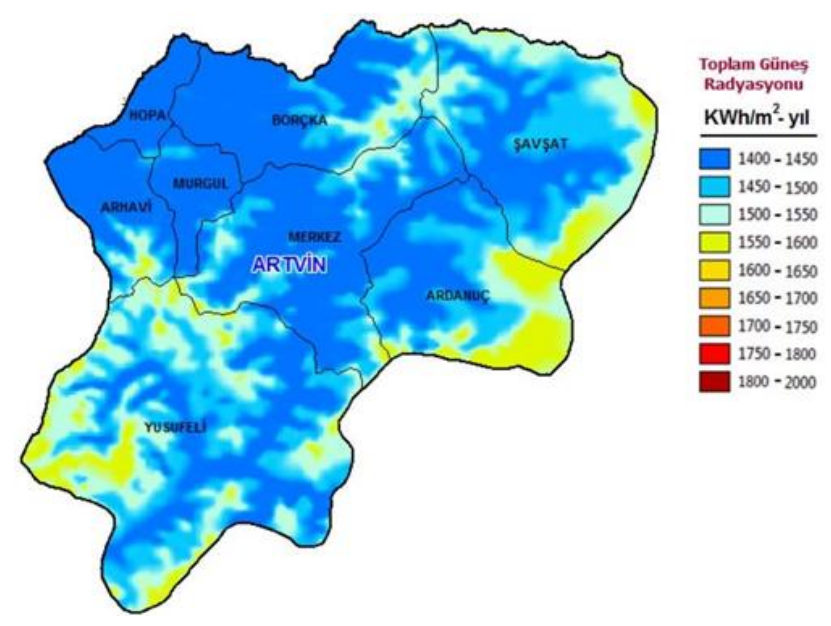

Fig. 1. Atlas of Artvin solar energy potential [18]

South-eastern Anatolia Region of Turkey has the solar potential with 2993 hours of annual sunshine duration. This is followed by the Mediterranean, Eastern Anatolia, Central Anatolia, Aegean and Marmara regions, respectively. The Black Sea region receives less sunlight than from other regions in Turkey. However, even the Black Sea region receives more sunshine than many European regions in the north that produce electricity from solar energy [18, 19].

Artvin province, located in the Black Sea region, has an area of $7367 \mathrm{~km}^{2}$, is between 40 '35' - 4132 'north latitudes and 4107 ' - 4200 'east longitude. Artvin, which is adjacent to Ardahan in the east, Erzurum in the south, Rize in the west and Georgia in the north, is the province that has changed most in the climate of the Eastern Black Sea Region [20]. Figure 1 shows solar energy potential of Artvin which has a potential of $1450-1500 \mathrm{KWh} / \mathrm{m}^{2}$ year in terms of total solar radiation. Ardanuç and Şavşat districts, which have a higher potential, are not suitable for establishing solar power plants (SEPs) in these areas due to their geographical location. Table 1 shows monthly global radiation values and sunshine times for Artvin. Turkey's average annual sunshine duration is 7,498 hours / day. Artvin's sunshine duration on April, May, June, July, August and September is above the Turkey average. There is no SEP currently established in Artvin. However, although it is not rich in solar energy in Artvin province, it will be advantageous in solar system installation with the use of developing technologies.

Table 1. Global Radiation Values and Sunshine Duration for Artvin [18]

\begin{tabular}{lcc}
\hline & $\begin{array}{c}\text { Global Radiation Value } \\
\left(\text { KWh/m } \mathbf{m}^{\mathbf{2}} \text {-day }\right)\end{array}$ & $\begin{array}{c}\text { Sunshine } \\
\text { Duration }(\mathbf{h r s})\end{array}$ \\
\hline January & 1.79 & 4.11 \\
February & 2.5 & 5.22 \\
March & 3.87 & 6.27 \\
April & 4.93 & 7.46 \\
May & 6.14 & 9.10 \\
June & 6.57 & 10.81 \\
July & 6.50 & 11.31 \\
August & 5.81 & 10.70 \\
September & 4.81 & 9.23 \\
October & 3.46 & 6.87 \\
November & 2.14 & 5.15 \\
December & 1.59 & 3.75 \\
\hline
\end{tabular}

\subsection{Wind energy}

Turkey's wind power potential areas are located in the mountain top, coastline, high ridges, or open space and the wind energy potential is about 48,000 MW. According to the regions, this potential can be sorted as Marmara, South eastern Anatolia, Aegean, Mediterranean, Black Sea and Eastern Anatolia. While the wind turbine installed capacity in the world is around 486,661 MW as of June 2017, the wind installed capacity in Turkey is $4718.3 \mathrm{MW}$, and it is increasing day by day. Considering wind energy, the provinces with the highest potential are Balıkesir with 767.3MW, İzmir with 613.6 MW, Manisa with 393.9 MW, Hatay with $277 \mathrm{MW}$ and Osmaniyewith $185 \mathrm{MW}$. In Turkey, the wind energy potential is $48.000 \mathrm{MW}$, while the available wind energy power is $4.718 .3 \mathrm{MW}$ that is only $10 \%$ of total potential. According to these figures, it is possible to conclude that especially the domestic wind turbines should be manufactured in order to fully utilize the wind energy potential [21]. Table 2 shows the monthly average wind speed and wind direction for Artvin. The wind is mainly in the northwest direction. According to 2017 data, annual average wind speed in Artvin was measured as $1.85 \mathrm{~m} / \mathrm{s}$ [22]. 
Table 2. Monthly Average Wind Speed and Wind Direction for Artvin [22]

\begin{tabular}{lcc}
\hline & $\begin{array}{c}\text { Monthly average } \\
\text { wind speed (m / s) }\end{array}$ & $\begin{array}{c}\text { Wind } \\
\text { direction }\end{array}$ \\
\hline January & 1.3 & $\mathrm{SE}$ \\
February & 1.6 & $\mathrm{SE}$ \\
March & 1.8 & $\mathrm{SSE}$ \\
April & 2.0 & $\mathrm{NNW}$ \\
May & 1.7 & $\mathrm{SSB}$ \\
June & 2.2 & $\mathrm{NW}$ \\
July & 2.6 & $\mathrm{NW}$ \\
August & 2.7 & $\mathrm{NW}$ \\
September & 1.9 & $\mathrm{NW}$ \\
October & 1.6 & $\mathrm{NW}$ \\
November & 1.3 & $\mathrm{SSE}$ \\
December & 1.5 & $\mathrm{NW}$ \\
\hline
\end{tabular}

\section{Statistical Methods}

\subsection{Weibull distribution}

Frequency distributions are used to determine the power potential of a region. If this is not possible, wind speed can be found with other analytical approaches such as the Weibull distribution. The Weibull distribution is generally an appropriate approach in wind energy analysis.

Furthermore, the Weibull distribution is a method with a low margin of error compared to other distributions. The parameter in eq. (1) is called as the scale parameter (c) which has the same unit as the wind speed. The scale parameter changes depending on the average speed. In other words, if the average speed is high, the scale parameter is also high. In the equation (2), the dimensionless shape parameter $(\mathrm{k})$ refers to the frequency of the wind. If the wind speed in a zone is at a constant speed, the speed value may be low or high; the shape parameter $(\mathrm{k})$ is large. If the wind speed is not at a constant speed, the shape parameter is small [4].

The scale parameter is defined as follows:

$$
c=\left(\frac{\sum_{i=1}^{n}\left(v_{i}\right)^{k}}{n}\right)^{\frac{1}{k}}
$$

The shape parameter is computed as follows:

$$
k=\left(\frac{\sum_{i=1}^{n} v_{i}^{k} \ln \left(v_{i}\right)}{\sum_{i=1}^{n} v_{i}^{k}}-\frac{\sum_{i=1}^{n} \ln \left(v_{i}\right)}{n}\right)^{-1}
$$

\subsection{Rayleigh distribution}

The change and distribution of wind over a period of time is very important for energy generation assessments. Turbine designers need information on wind distribution and change in turbine improvement and minimizing costs. If only the average wind speed ( $\left.\mathrm{V}_{\text {rort }}\right)$ is known in one place, with the help of the Rayleigh Dispersion Function any wind speed $\left(\mathrm{V}_{\mathrm{ri}}\right)$ can be found as a percentage of blowing time $\left(\mathrm{h}_{\mathrm{r}}\right)$. The resulting wind speeds are a probability density distribution. The Rayleigh distribution is used to calculate the distribution of wind velocity. In this distribution, the shape parameter is set to the constant value " 2 ". In this case, Rayleigh density function can be defined by the equation $[3,4]$.

$$
f_{R}(v)=\left(\frac{2 v}{c^{2}}\right) \exp \left(-\left(\frac{v}{c}\right)^{2}\right)
$$

Rayleigh cumulative distribution function is follows:

$$
F_{R}(v)=1-\exp \left(-\left(\frac{v}{c}\right)^{2}\right)
$$

The average wind speed and power density for the Rayleigh distribution are given as:

$$
\begin{aligned}
& v_{m}=c \sqrt{\pi / 4} \\
& P_{R}=\frac{3}{\pi} \rho v_{m}^{3}
\end{aligned}
$$

The main advantage of the Rayleigh distribution is the determination of the distribution only by the average wind speed.

\subsection{Gamma distribution}

If " $n$ " is an integer value representing randomly varying wind velocity observation values, the Gamma distribution represents the sum of $\mathrm{n}$ random exponential distributions. This also is applied to wind speed data, which varies depending on geographic location and climate regime. Gama Distribution probability density function is calculated as follows [2]:

$$
f(v)=v^{k-1} \frac{\exp \left(\frac{-v}{c}\right)}{c^{k} \Gamma(k)} \quad \text { k. } c>0
$$

Where $\mathrm{k}$ is the shape parameter and $\mathrm{c}$ is the scale parameter. The cumulative distribution function of the gamma distribution is defined as [2]:

$$
F(v)=\frac{\gamma\left(k, \frac{v}{c}\right)}{\Gamma(k)}
$$

In eq. (8), $\gamma($.$) refers to the incomplete gamma function.$

\subsection{Lognormal distribution}

The probability density function of log-normal (LN) distribution based on normal distribution is computed as follows [2]:

$$
f(v)=\frac{\exp \left(-\ln \left(\frac{v}{c}\right)^{2}\right) / 2 k^{2}}{v k \sqrt{2 \pi}} \quad c>0
$$

where $\Phi$ is the cumulative distribution function of the standard normal distribution. Thus the cumulative distribution function of the LND is calculated as follows:

$$
F(v)=\phi\left(\frac{\ln \left(\frac{v}{c}\right)}{k}\right)
$$


The zero required for the calculation of this distribution power can be obtained by taking $r=3$ in the following moment equation.

$$
\mu_{r}=E\left(v^{r}\right)=\exp \left(r \mu+0.5 r^{2} c^{2}\right)
$$

\section{Statistical Analysis of Wind Energy Potential}

The estimation of the shape and scale parameters was performed using data from station 17045 between June 2017 and August 2018. The 16-month data obtained from Artvin Central Station is shown in Table 3 and Table 4 [22]. In this study, calculations were done using the 10659 data.

Weibull power density and parameter calculations are given in Table 5 for 2017 and 2018. Table 6 shows Rayleigh power density and parameter calculations of the same year and month. Gamma and Lognormal distribution results for the same parameters are given in Table 7 and 8 . All calculations for four distributions were performed using hourly wind data. In Rayleigh distribution, the value $(\mathrm{k})$ is considered to be 2 and the value in Table 6 is not specified. The parameters in Table 5 are mean speed $(\mathrm{vm})$, standard deviation $(\sigma)$, wind speed probability iw $(v)$, cumulative wind speed $\mathrm{Fw}(v)$, wind speed, maximum possible energy density Vmax E, maximum wind, and the average energy density for the rate $(\mathrm{P} / \mathrm{A})$. These calculations were performed using Matlab Platform. In addition, the average energy density is used as $\mathrm{P}=1.226$.
Table 3. Hourly wind speed data for Artvin for 2017

\begin{tabular}{lc}
\hline \multicolumn{1}{c}{$\mathbf{2 0 1 7}$} & Measured hourly data \\
\hline June & 689 \\
July & 678 \\
August & 658 \\
September & 578 \\
October & 704 \\
November & 622 \\
December & 648 \\
Total & 4577 \\
\hline
\end{tabular}

Table 4. Hourly wind speed data for Artvin for 2018

\begin{tabular}{cc}
\hline 2017 & Measured hourly data \\
\hline January & 692 \\
February & 649 \\
March & 728 \\
April & 698 \\
May & 730 \\
June & 695 \\
July & 744 \\
August & 726 \\
September & 420 \\
Total & 6082 \\
\hline
\end{tabular}

Table 5. Velocity and power prediction for Weibull distrubution

\begin{tabular}{|c|c|c|c|c|c|c|c|c|c|}
\hline Months & $\mathbf{k}$ & c & $\mathbf{V m}(\mathbf{m} / \mathbf{s})$ & $\sigma(\mathbf{m} / \mathbf{s})$ & $f w(v)$ & $\mathbf{F w}(\mathbf{v})$ & Venolası (m/s) & $V \max E(m / s)$ & $\mathbf{P} / \mathbf{A}\left(\mathbf{w} / \mathbf{m}^{2}\right)$ \\
\hline June 2017 & 1.1188 & 2.3138 & 2.2205 & 1.9881 & 0.1852 & 0.6152 & 0.3116 & 5.7849 & 6.7110 \\
\hline July 2017 & 1.2572 & 2.8587 & 2.6591 & 2.1290 & 0.1732 & 0.5987 & 0.8091 & 6.0958 & 11.5253 \\
\hline August 2017 & 1.1732 & 2.8567 & 2.7034 & 2.3119 & 0.1593 & 0.6083 & 0.5595 & 6.6708 & 12.1114 \\
\hline September 2017 & 1.1325 & 2.0042 & 1.9161 & 1.6954 & 0.2172 & 0.6134 & 0.3015 & 4.9213 & 4.3125 \\
\hline October 2017 & 1.5023 & 1.8219 & 1.6444 & 1.1150 & 0.3323 & 0.5757 & 0.8786 & 3.2005 & 2.7258 \\
\hline November 2017 & 1.4622 & 1.5212 & 1.3778 & 0.9578 & 0.3865 & 0.5790 & 0.6920 & 2.7430 & 1.6032 \\
\hline December 2017 & 2.3960 & 1.8296 & 1.6218 & 0.7209 & 0.5232 & 0.5272 & 1.4603 & 2.3569 & 2.6150 \\
\hline January 2018 & 1.4968 & 1.7415 & 1.5725 & 1.0698 & 0.3463 & 0.5761 & 0.8336 & 3.0698 & 2.3838 \\
\hline February 2018 & 1.6023 & 1.7417 & 1.5614 & 0.9978 & 0.3721 & 0.5680 & 0.9458 & 2.8878 & 2.3334 \\
\hline March 2018 & 1.4565 & 1.9790 & 1.7933 & 1.2511 & 0.2959 & 0.5795 & 0.8923 & 3.5821 & 3.5353 \\
\hline April 2018 & 1.2163 & 1.9814 & 1.8575 & 1.5346 & 0.2402 & 0.6032 & 0.4791 & 4.4075 & 3.9287 \\
\hline May 2018 & 1.1847 & 1.6470 & 1.5545 & 1.3171 & 0.2797 & 0.6069 & 0.3431 & 3.7950 & 2.3027 \\
\hline June 2018 & 1.1174 & 2.0625 & 1.9801 & 1.7750 & 0.2074 & 0.6154 & 0.2745 & 5.1661 & 4.7588 \\
\hline July 2018 & 1.4085 & 3.0544 & 2.7812 & 2.0016 & 0.1848 & 0.5837 & 1.2685 & 5.7202 & 13.1877 \\
\hline August 2018 & 1.3606 & 3.0755 & 2.8164 & 2.0933 & 0.1765 & 0.5882 & 1.1584 & 5.9777 & 13.6938 \\
\hline September 2018 & 1.3213 & 2.4849 & 2.2877 & 1.7477 & 0.2113 & 0.5920 & 0.8521 & 4.9921 & 7.3391 \\
\hline
\end{tabular}

According to these results, two criteria are used to understand which of these four distributions performed better. One of them is the coefficient of determination method $\left(\mathrm{R}^{2}\right)$, the other is the wind power error criterion method (WPE).

The coefficient of determination $\left(\mathrm{R}^{2}\right)$ is calculated as [4]:

$$
R^{2}=\frac{\sum_{i=1}^{n}\left(y_{i}-z_{i}\right)^{2}-\sum_{i=1}^{n}\left(y_{i}-x_{i}\right)^{2}}{\sum_{i=1}^{n}\left(y_{i}-z_{i}\right)^{2}}
$$

Where yi is wind speed, $x i$ is the data estimated from the Weibull, Rayleigh, Gamma or Lognormal distribution. $\mathrm{N}$ and zi represents the total number of data and the mean value, respectively. In this equation, $R^{2}$ is between 0 and 1 . The wind power error (WPE) is defined as follows [7]:

$$
W P E=\left|\frac{P_{R E F}-P_{D}}{P_{R E F}}\right| * 100
$$

Where, PD is the distribution of wind power based on distribution. In eq. (13), the distribution with a small WPE value is considered as a good distribution. If the wind power density given in Tables 5, 6, 7 and 8 is above $50 \mathrm{~W} / \mathrm{m} 2$, the 
wind turbine can be installed in this zone. It should be noted, however, that the measurements taken from meteorological stations are carried out at an altitude of $10 \mathrm{~m}$ and should therefore be taken into account when evaluating the calculated power densities. Table 9 shows the Wind Power
Errors for four distributions. The distribution that provides the smallest WPE value will be considered as the most appropriate solution. Table 10 shows the coefficient of determination $\mathrm{R}^{2}$ for the four distributions. The distribution with the closest value to 1 is the most appropriate modelling.

Table 6. Velocity and power prediction for Rayleigh distrubution

\begin{tabular}{|l|c|l|l|l|l|l|l|c|}
\hline \multicolumn{1}{|c|}{ Months } & $\mathbf{c}$ & $\mathbf{V}_{\mathbf{m}}(\mathbf{m} / \mathbf{s})$ & $\boldsymbol{\sigma} \mathbf{( m / s )}$ & $\mathbf{f w}(\mathbf{v})$ & $\mathbf{F w}(\mathbf{v})$ & $\mathbf{V}_{\text {enolasi }}(\mathbf{m} / \mathbf{s})$ & $\mathbf{V}_{\mathbf{m a x}} \mathbf{E}(\mathbf{m} / \mathbf{s})$ & $\mathbf{P} / \mathbf{A}\left(\mathbf{w} / \mathbf{m}^{\mathbf{2}}\right)$ \\
\hline June 2017 & 2.8854 & 2.5571 & 0.9732 & 0.0449 & 0.9844 & 2.0403 & 4.0805 & 19.5751 \\
\hline July 2017 & 3.3005 & 2.9250 & 1.1133 & 0.0142 & 0.9957 & 2.3338 & 4.6676 & 29.2975 \\
\hline August 2017 & 3.3961 & 3.0098 & 1.1455 & 0.0106 & 0.9969 & 2.4014 & 4.8029 & 31.9195 \\
\hline September 2017 & 2.4179 & 2.1428 & 0.8156 & 0.1300 & 0.9462 & 1.7097 & 3.4194 & 11.5186 \\
\hline October 2017 & 2.0234 & 1.7932 & 0.6825 & 0.2612 & 0.8709 & 1.4308 & 2.8615 & 6.7506 \\
\hline November 2017 & 1.6220 & 1.4375 & 0.5471 & 0.4353 & 0.7316 & 1.1469 & 2.2938 & 3.4773 \\
\hline December 2017 & 1.7075 & 1.5132 & 0.5759 & 0.3974 & 0.7672 & 1.2074 & 2.4148 & 4.0567 \\
\hline January 2018 & 1.9356 & 1.7153 & 0.6529 & 0.2974 & 0.8464 & 1.3687 & 2.7373 & 5.9091 \\
\hline February 2018 & 1.8280 & 1.6200 & 0.6166 & 0.3438 & 0.8119 & 1.2926 & 2.5852 & 4.9777 \\
\hline March 2018 & 2.3107 & 2.0478 & 0.7794 & 0.1601 & 0.9307 & 1.6339 & 3.2678 & 10.0537 \\
\hline April 2018 & 2.4653 & 2.1848 & 0.8316 & 0.1181 & 0.9521 & 1.7432 & 3.4865 & 12.2101 \\
\hline May 2018 & 2.1715 & 1.9244 & 0.7324 & 0.2055 & 0.9054 & 1.5355 & 3.0709 & 8.3439 \\
\hline June 2018 & 2.6906 & 2.3845 & 0.9075 & 0.0721 & 0.9732 & 1.9025 & 3.8051 & 15.8725 \\
\hline July 2018 & 3.1702 & 2.8095 & 1.0693 & 0.0208 & 0.9934 & 2.2417 & 4.4834 & 25.9637 \\
\hline August 2018 & 3.1060 & 2.7526 & 1.0477 & 0.0250 & 0.9920 & 2.1963 & 4.3925 & 24.4168 \\
\hline September 2018 & 1.9596 & 1.7367 & 0.6610 & 0.2873 & 0.8534 & 1.3857 & 2.7714 & 6.1324 \\
\hline
\end{tabular}

Table 7. Velocity and power prediction for Gamma distrubution

\begin{tabular}{|c|c|c|c|c|c|c|c|c|c|}
\hline Months & $\mathbf{k}$ & c & $\mathrm{Vm}(\mathrm{m} / \mathrm{s})$ & $\sigma(\mathrm{m} / \mathrm{s})$ & $f w(v)$ & Fw(v) & Venolası $(\mathrm{m} / \mathbf{s})$ & $V_{\max } \mathbf{E}(\mathrm{m} / \mathrm{s})$ & $\mathbf{P} / \mathbf{A}\left(\mathbf{w} / \mathbf{m}^{2}\right)$ \\
\hline June 2017 & 1.1780 & 1.8855 & 2.0518 & 0.5764 & 0.1819 & 0.6220 & 1.2253 & 2.6847 & 6.7163 \\
\hline July 2017 & 1.3299 & 2.0077 & 2.5521 & 0.6139 & 0.1620 & 0.6150 & 1.2979 & 2.5814 & 11.6689 \\
\hline August 2017 & 1.2162 & 2.2287 & 2.6213 & 0.5109 & 0.1518 & 0.6201 & 1.4006 & 2.4386 & 12.2077 \\
\hline September 2017 & 1.2768 & 1.4969 & 1.1682 & 0.7843 & 0.2212 & 0.6173 & 0.8758 & 3.2248 & 4.2802 \\
\hline October 2017 & 1.9779 & 0.8302 & 1.2589 & 2.6463 & 0.3277 & 0.5945 & 0.2706 & 8.0148 & 2.7143 \\
\hline November 2017 & 1.9250 & 0.7146 & 1.1326 & 3.4137 & 0.3855 & 0.5958 & 0.5063 & 11.8421 & 1.5958 \\
\hline December 2017 & 4.7689 & 0.3411 & 1.4516 & 1.0949 & 0.3623 & 0.5953 & 0.4821 & 7.7714 & 2.3316 \\
\hline January 2018 & 1.9631 & 0.8001 & 1.7835 & 2.8032 & 0.3412 & 0.5949 & 0.3469 & 9.3957 & 2.3751 \\
\hline February 2018 & 2.2310 & 0.6993 & 1.9814 & 4.1382 & 0.3680 & 0.5890 & 0.6672 & 15.3913 & 2.3282 \\
\hline March 2018 & 2.0437 & 0.8727 & 1.3254 & 2.5149 & 0.3071 & 0.5930 & 0.2251 & 8.0047 & 3.4776 \\
\hline April 2018 & 1.4117 & 1.3126 & 1.1232 & 1.0003 & 0.2413 & 0.6117 & 0.4732 & 2.8578 & 3.9008 \\
\hline May 2018 & 1.4368 & 1.0765 & 1.2262 & 1.2984 & 0.2920 & 0.6107 & 0.1231 & 3.8111 & 2.2679 \\
\hline June 2018 & 1.2378 & 1.5964 & 1.4284 & 0.7118 & 0.2103 & 0.6191 & 0.6680 & 2.0588 & 4.7300 \\
\hline July 2018 & 1.6619 & 1.6744 & 2.7219 & 0.9113 & 0.1759 & 0.6030 & 0.9655 & 2.6574 & 13.2092 \\
\hline August 2018 & 1.6068 & 1.7516 & 2.4215 & 0.8432 & 0.1707 & 0.6048 & 0.9913 & 2.4821 & 13.6683 \\
\hline September 2018 & 1.6817 & 1.3528 & 2.1321 & 1.1519 & 0.2165 & 0.6024 & 0.6227 & 3.2894 & 7.2186 \\
\hline
\end{tabular}

Table 8. Velocity and power prediction for Lognormal distrubution

\begin{tabular}{|c|c|c|c|c|c|c|c|c|c|}
\hline Months & $\mathbf{k}$ & c & $\mathrm{Vm}(\mathrm{m} / \mathrm{s})$ & $\sigma(\mathrm{m} / \mathrm{s})$ & $f w(v)$ & $\mathbf{F w}(\mathbf{v})$ & Venolası (m/s) & $\operatorname{Vmax} E(m / s)$ & $\mathbf{P} / \mathbf{A}\left(\mathbf{w} / \mathbf{m}^{2}\right)$ \\
\hline June 2017 & 0.3169 & 1.1082 & 2.1223 & 0.2756 & 0.1217 & 0.7103 & 0.8015 & 2.8015 & 10.0089 \\
\hline July 2017 & 0.5612 & 1.0824 & 2.5813 & 0.5035 & 0.1011 & 0.7058 & 0.0520 & 3.4758 & 19.1351 \\
\hline August 2017 & 0.5327 & 1.1275 & 2.6115 & 0.4532 & 0.0938 & 0.7135 & 0.0771 & 3.3116 & 20.4036 \\
\hline September 2017 & 0.2076 & 1.0166 & 1.0478 & 0.2028 & 0.1671 & 0.6944 & 0.0036 & 2.6052 & 5.3858 \\
\hline October 2017 & 0.2224 & 0.8210 & 1.3189 & 0.3033 & 0.2553 & 0.6593 & 0.0347 & 2.9999 & 3.2833 \\
\hline November 2017 & 0.0372 & 0.8387 & 1.3365 & 0.0490 & 0.2953 & 0.6625 & 0.0052 & 2.1594 & 1.9687 \\
\hline December 2017 & 0.3782 & 0.5115 & 1.4225 & 0.5722 & 0.4537 & 0.6009 & 0.3454 & 10.4841 & 2.8226 \\
\hline January 2018 & 0.1757 & 0.8297 & 1.7715 & 0.2353 & 0.2623 & 0.6609 & 0.0260 & 2.7707 & 2.9158 \\
\hline February 2018 & 0.2043 & 0.7792 & 1.9741 & 0.3061 & 0.2856 & 0.6516 & 0.0405 & 3.0448 & 2.8125 \\
\hline March 2018 & 0.3144 & 0.7740 & 1.3132 & 0.4770 & 0.2588 & 0.6506 & 0.0641 & 3.6358 & 3.8667 \\
\hline April 2018 & 0.2226 & 0.9735 & 1.1192 & 0.2314 & 0.1814 & 0.6868 & 0.0055 & 2.7010 & 4.9529 \\
\hline May 2018 & 0.0494 & 0.9250 & 1.2867 & 0.0554 & 0.2405 & 0.6781 & 0.0032 & 2.1713 & 2.5655 \\
\hline June 2018 & 0.2256 & 1.0295 & 1.4536 & 0.2166 & 0.1595 & 0.6966 & 0.0071 & 2.6438 & 5.9130 \\
\hline July 2018 & 0.6934 & 0.8985 & 2.7534 & 0.8141 & 0.1340 & 0.6734 & 0.0612 & 4.5531 & 16.4716 \\
\hline August 2018 & 0.6925 & 0.9060 & 2.4529 & 0.8025 & 0.1319 & 0.6747 & 0.0567 & 4.5067 & 16.7624 \\
\hline September 2018 & 0.4961 & 0.8362 & 2.1458 & 0.6558 & 0.1877 & 0.6621 & 0.0706 & 4.1379 & 7.7506 \\
\hline
\end{tabular}

Figure 2 and 3 show a comparison of Weibull, Rayleigh, Gamma and Lognormal distributions according to $\mathrm{R}^{2}$ and
WPE criteria for 2017 and 2018 data. As shown in Figure 2 and 3 , the weibull distribution produces better results than 
other distributions. Secondly, Gamma distribution was found to be better. In the figures, the results are considered to be better in which the coefficient of determination is approached

Table 9. Wind power errors for Weibull, Rayleigh, Gamma, Lognormal distributions

\begin{tabular}{|c|c|c|c|c|}
\hline Months & Weibull & Rayleigh & Gamma & Lognormal \\
\hline June 2017 & 54.5956 & 63.4453 & 54.6099 & 62.3700 \\
\hline July 2017 & 86.2064 & 95.0406 & 86.5630 & 102.0780 \\
\hline August 2017 & 101.0062 & 113.6495 & 101.2732 & 120.1855 \\
\hline September 2017 & 737.2024 & 44.5325 & 37.1091 & 40.0630 \\
\hline October 2017 & 12.5463 & 13.4713 & 12.5285 & 13.3491 \\
\hline November 2017 & 76.9653 & 7.5676 & 6.9546 & 7.4588 \\
\hline December 2017 & 7.0367 & 6.8095 & 7.0587 & 7.2182 \\
\hline January 2018 & 10.5979 & 11.3911 & 10.5851 & 11.3341 \\
\hline February 2018 & 9.5421 & 10.0676 & 9.5349 & 10.1550 \\
\hline March 2018 & 20.3883 & 22.3170 & 20.2767 & 21.0065 \\
\hline April 2018 & 28.1584 & 32.5188 & 28.0927 & 30.4201 \\
\hline May 2018 & 17.1413 & 20.5255 & 17.0546 & 17.7700 \\
\hline June 2018 & 40.1938 & 47.9372 & 40.1128 & 43.2114 \\
\hline July 2018 & 95.4768 & 103.0638 & 95.5285 & 102.8220 \\
\hline August 2018 & 107.0435 & 117.0124 & 106.9768 & 114.5066 \\
\hline September 2018 & 856.1349 & 63.0667 & 55.8260 & 57.1652 \\
\hline
\end{tabular}

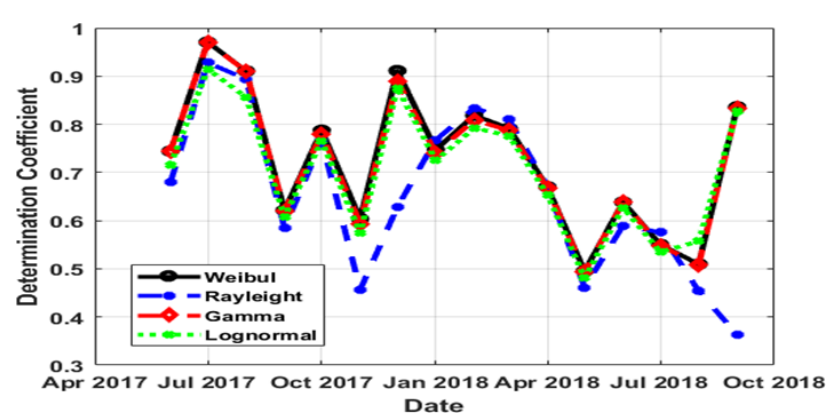

Fig. 2. $\mathrm{R}^{2}$ values for Weibull, Rayleigh, Gamma and Lognormal

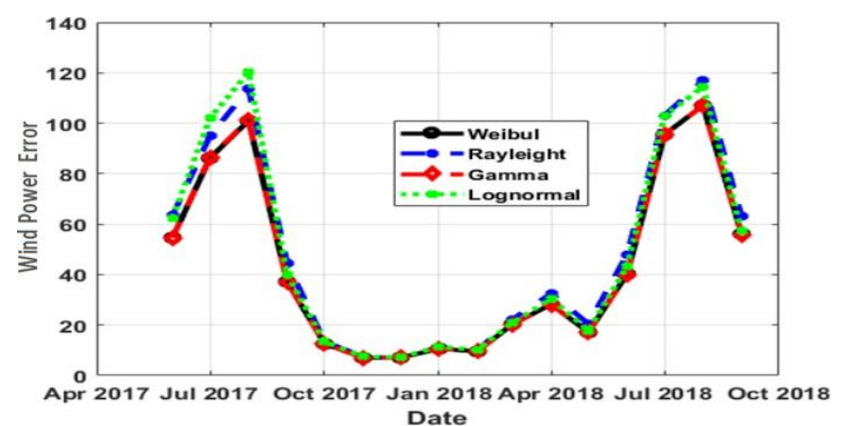

Fig. 3. Wind power errors (WPE) for Weibull, Rayleigh, Gamma and Lognormal

\section{Conclusions}

In this study, the wind power potential of Artvin Region was investigated by using Weibull, Rayleigh, Gamma and Lognormal distributions. The wind power densities were to 1 and so has less fluctuation. A low WPE value means that the model has a low error rate, and therefore it is a good result.

Table 10. $\mathrm{R}^{2}$ values for Weibull, Rayleigh, Gamma, Lognormal distributions

\begin{tabular}{|c|c|c|c|c|}
\hline Months & Weibull & Rayleigh & Gamma & Lognormal \\
\hline June 2017 & 0.7444 & 0.6797 & 0.7437 & 0.7154 \\
\hline July 2017 & 0.9706 & 0.9280 & 0.9699 & 0.9146 \\
\hline August 2017 & 0.9106 & 0.8938 & 0.9101 & 0.8564 \\
\hline September 2017 & 0.6213 & 0.5845 & 0.6203 & 0.6083 \\
\hline October 2017 & 0.7874 & 0.7662 & 0.7802 & 0.7653 \\
\hline November 2017 & 0.6038 & 0.4566 & 0.5940 & 0.5737 \\
\hline December 2017 & 0.9113 & 0.6281 & 0.8894 & 0.8755 \\
\hline January 2018 & 0.7474 & 0.7676 & 0.7402 & 0.7250 \\
\hline February 2018 & 0.8187 & 0.8342 & 0.8091 & 0.7922 \\
\hline March 2018 & 0.7916 & 0.8100 & 0.7870 & 0.7763 \\
\hline April 2018 & 0.6703 & 0.6708 & 0.6682 & 0.6541 \\
\hline May 2018 & 0.4951 & 0.4612 & 0.4937 & 0.4810 \\
\hline June 2018 & 0.6385 & 0.5896 & 0.6377 & 0.6270 \\
\hline July 2018 & 0.5504 & 0.5758 & 0.5485 & 0.5353 \\
\hline August 2018 & 0.5097 & 0.4538 & 0.5080 & 0.9971 \\
\hline September 2018 & 0.8361 & 0.3633 & 0.8339 & 0.8278 \\
\hline
\end{tabular}

compared with statistical criteria. Weibull distribution was found to be more stable than other methods. Secondly Gamma distribution produced better results than other distributions. In addition, a short overview was given about the solar energy potential in Artvin. Although the solar potential of April, May, June, July, August and September is above the average of Turkey, it cannot be said that it has still great potential in terms of solar energy. These results provide an insight in terms of increasing investments in renewable energy sources and contributing to realization of new investments in Artvin province.

\section{References}

[1] Teias, https://www.teias.gov.tr/en/elektrik-istatistikleri [Visit Date: 15 August 2018], 2018.

[2] Cho H., Bowman, K., North, G., "A Comparison of Gamma and Lognormal Distributions for Characterizing Satellite Rain Rates from the Tropical Rainfall Measuring Mission”, Journal Of Applied Meteorology, p.1586, v.43, 2004.

[3] Kurban, M., Hocaoglu, F. O., and Kantar, Y. M., “A Comparative Analysis of Two Different Statistical Distributions Used in Forecasting Wind Energy Potential", Pamukkale University Faculty of Engineering, Engineering Sciences Journal, Denizli, 106, 2007. 
[4] Z. Demirkol, M.Cunkas "Renewable Energy Potential of Afyonkarahisar Province" Journal of Eng. Science and Technology. c.2, p.1, v.2, n.1, 2014 ISSN: 2147-9364, 2014.

[5] Köse, B., Güneşer, M., Yazıcı, M., Yılmaz, S., "Estimation of Wind Energy Potential Eskipazar Using Rayleigh, Lognormal and Weibull Distribution Model", International Symposium On Innovate Technologies In Engineering And Science (ISITES), v.1, Universidad Polinectica de Valencia, Spain, 2015.

[6] Balpetek, N., Akpınar, E., "Statistical analysis of wind energy potential of Elazığ province according to Weibull and Rayleigh distributions", Journal of the Faculty of Engineering and Architecture of Gazi University, ISSN: 5000213345, Ankara, 2017.

[7] Usta, i., Kantar Y., M., "Wind Power Potential Estimation By Using Different Statiscal Distributions”, Dokuz Eylül University Faculty of Engineering, Journal of Engineering and Sciences, c.2, p.362, v.18, n.3, 2016.

[8] Emeksiz, C., Doğan, Z., Gökrem, L., Yavuz, H., "Analyzing The Wind Characteristics of Tokat Region With Statistical Methods, Gaziosmanpaşa University Faculty of Engineering and Natural Sciences, Journal of Polytechnic, c.4, p.481-489, Tokat, 2016.

[9] Sohoni A.V, Gupta S.,, Nema R.,"Comparative analysis of wind speed probability distributions for wind power assessment of four sites", . Turk J Elec Eng \& Comp Sci, 24: 4724-4735, 2016.

[10] Aydin E.H., Çunkaş M., "Overview of Potential of Renewable Energy Sources in Artvin Province", International Conference on Engineering Technologies (ICENTE'18), pp. 325-329, October 26-28,2018, Konya/TURKEY.

[11] Öztürk, H. H, "Solar Energy and Applications" Birsen Publishing House, Adana, 2012.

[12] Kamil B. Varınca, Gamze Varank, "Evaluation of Environmental Impacts in Wind Source Energy Generation Systems and Solutions", New and Renewable Energy Resources / Energy Management Symposium, p. 367-376, 2005

[13] Energy and Natural Resources Ministry "Milges, Milhes, Milkanat and (YGDA) System Development Projects" Ankara, 2015.

[14] South Marmara Development Agency https://www.gmka.gov.tr/ [Visit Date: 20 February 2019], 2019.

[15] Republic of Turkey Ministry of Energy and Natural Resources http://www.enerji.gov.tr/trTR/Sayfalar/Gunes, [Visit Date: 25 February 2019], 2018.

[16] World Energy Council Turkish National Committee https://www.dunyaenerji.org.tr/yenilenebilir- enerjiler- 2018-kuresel-durum-raporu/ [Visit Date: 10 February 2019], 2018.

[17] The International Renewable Energy Agency (IRENA)) https://www.irena.org/ [Visit Date: 19 February 2019], 2019.

[18] Yegm,http://www.yegm.gov.tr/MyCalculator/pages/8. aspx [Visit Date: 10 August 2018], 2018.

[19] Varınca, K. B., Gönüllü, M. T., "Solar energy potential and the use degree of potential in Turkey, Management and Prevalence A Study on the" First National Solar and Hydrogen Energy Congress, Eskisehir, 270-274, 2006.

[20] Artvin Governorent, http://www.artvin.gov.tr/ [Visit Date: 25 August 2018], 2018

[21] Ekolojist.net,http://ekolojist.net/ruzgarin-potansiyeline/ [Visit Date: 18 August 2018], 2018.

[22] Mgm, https://www.mgm.gov.tr/dataevaluation / il-veilceler-statistic.aspx? M = ARTVIN [Visit Date: 18 July 2018], 2018

[23] Enerji Atlas1, http://www.enerjiatlasi.com/gunes/[Visit Date: 10 August 2018], 2018

[24] Enerji Atlas1, http://www.enerjiatlasi.com/ruzgar/ [Visit Date: 10 August 2018], 2018.

[25] Mathworks.com, https://www.mathworks.com/examples/matlab [Visit Date: 15 February 2019], 2019. 